\title{
The Vienna circles: cultivating economic knowledge outside academia
}

\author{
ERWIN DEKKER \\ Erasmus University Rotterdam
}

\begin{abstract}
This article examines the intellectual scenery of interwar Vienna. It argues that its central institution was not academia, but rather the circles ('Kreise'). The prominence of these circles can partly account for the creative outburst in the social sciences in interwar Vienna. The article also helps to explain the peculiar character of the knowledge produced in interwar Vienna which is just as much concerned with social and political issues as it is with more traditional scientific issues. The lack of formal institutions and the marginal position of the University of Vienna also had downsides. It caused uncertainty in terms of career prospects and professional identities, although the informal interaction within the circles full of rituals and alternative institutions could partly make up for this. The uncertain future for scholars ultimately contributed to the enormous wave of migration from Vienna, frequently even before the political situation became an acute threat.
\end{abstract}

Keywords: Austrian school of economics, Vienna circle, interwar Vienna, economic practices

JEL Classification: B13, B25, B53, Z13

Fin-de-siècle Vienna has been widely studied for the creative outburst in both the arts and the sciences (see, e.g., Johnston 1972; Janik and Toulmin 1973; Schorske 1980). And understandably so, just think about the abundance of contributions across an enormous breadth: in physics (Mach and Boltzmann), in psychology (Freud and Adler), in the visual arts (Klimt, Kokoschka, and Schiele) in music (Mahler, Schönberg, and Berg), in architecture (Wagner and Loos), in literature (Hoffmanstahl, Roth, Musil, and Zweig) and in cultural criticism (Kraus). In some of the sciences, however the more important period was the interwar period which has attracted less attention. In philosophy, the Wiener Kreis and Karl Popper shaped the interwar scene. In economics, Othmar Spann a 
German romantic competed with at least three alternative approaches to economics: Austro-Marxism, Austro-liberalism, and the emerging mathematical economists. Hans Kelsen developed his pure theory of law, Hermann Broch wrote his most important works, and some of the artists mentioned above continued to contribute (Leser 1981). Intellectually Vienna continued to flourish. An obvious question that emerges from that fact is whether there was something peculiar about Vienna during that period.

Schorske's explanation of the outburst of the fin-de-siècle period has attracted most attention, although his complex argument is not easily summarized. Schorske argues that political liberalism never gained a strong foothold in Vienna, and therefore the bourgeoisie turned to culture as an alternative outlet. He furthermore suggests that the collapse of the moral order and the failure of political liberalism generated a tension which allowed the Viennese intellectuals to foresee as it were, the twentieth century (Schorske 1980).

Other commentators have emphasized the Jewish background of many of the contributors to this Viennese culture (Beller 1989; Wistrich 1996). Additionally we should not neglect the fact that the Viennese society, especially pre-WWI, was extremely unequal. The cultural (and political) elite was formed by a couple of hundred families who were often related by blood or through recent marriages. To give just one example, economists Böhm-Bawerk and Wieser were life-long friends, who attended the same prestigious gymnasium, later they both served in various political functions. Böhm-Bawerk later became minister of finance, and Wieser was appointed minister of commerce. Böhm-Bawerk also married Wieser's sister. ${ }^{1}$ Or take Hayek's description of the personal relations in Vienna:

I began to go through the list [of famous people from Vienna], and I found I knew almost every one of them personally. And with most of them I was somehow connected by friendship or family relations and so on. I think the discussion began, 'Did you know Schrödinger?' 'Oh, yes, of course; Schrödinger was the son of a colleague of my father's and came as a young man in our house'. Or, '[Karl von] Frisch, the bee Frisch?' 'Oh yes, he was the youngest of a group of friends of my father's; so we knew the family quite well. 'Or, Lorenz?' 'Oh, yes, I know the whole family. I've seen Lorenz watching

\footnotetext{
${ }^{1}$ For a more general discussion of the importance of 'families' in Vienna, see Coen 2007.
} 
ducks when he was three years old'. And so it went on (Hayek 1979, 7-8).

And then Hayek is not even mentioning his family relations to the Wittgenstein family. We are familiar with Ludwig the philosopher, but Maurice Ravel wrote his famous 'Piano Concerto for Left Hand' for Ludwig's brother Paul, an accomplished pianist, who lost his right hand during the War. The cultural world of pre-WWI Vienna in other words, is ill-described as cosmopolitan, it was a small village.

The situation, however, was different during the interwar period. Far from turned inward many intellectuals were politically motivated and active. Economic as well as social differences were diminishing and many migrants arrived, especially from the east following the break-up of the Habsburg Empire. During that period, the most important economic Viennese circles are to be found (although they sometimes had pre-WWI predecessors). This paper argues that to understand the outburst of the interwar period it is essential to study the Viennese circles ('Kreise'). We are well acquainted with the most famous of them, the Wiener Kreis: a circle of logical positivists around Moritz Schlick. Interwar Vienna, however, was filled with such circles. In a recent article, Timms has produced a visual representation of these scientific and artistic circles in Vienna in which he suggests that there were as many as fifty (Timms 2009, 25). ${ }^{2}$ Perhaps even more striking than the sheer number of these circles is their overlap. Above we have already emphasized the importance of personal relationships, but these were further cultivated through the participation in a number of partly overlapping circles. If one did not know someone directly, he was never more than one or two circles away. ${ }^{3}$ The historian and economist EngelJanosi, for example, belonged to four of such circles (Engel-Janosi 1974, 108-128). It should hence come as no surprise that gossip was pervasive in Viennese society; social bonds were thick.

A proper understanding of these circles is crucial to understand the contribution of the economists from Vienna for three reasons. First,

\footnotetext{
${ }^{2}$ It is not precisely clear which time period Timms's picture represents, but at least some of the circles in his figure never existed simultaneously. An earlier version of the picture suggests that it shows the situation in the late 1920s, see Timms 1993.

${ }^{3}$ One exception should be mentioned, there was a more strict segregation between Jewish and non-Jewish circles. This is also emphasized by Hayek in the interview cited above. On the other hand assimilated Jews were regularly fully respected members of non-Jewish circles.
} 
because their work was the outcome of the debates between 'members' of these circles, ${ }^{4}$ the circles are the most important intellectual context. Secondly the character of the knowledge that emerged from these circles differed from that produced in strictly academic settings. While in many other European countries modern universities were coming to dominate the intellectual atmosphere, Viennese intellectual life took place within the social sphere. While knowledge and artistic production became organized along disciplinary lines in many other European countries (and the U.S.A.), intellectual life in Vienna remained both broad and relatively informal. While in many other countries theoretical concerns came to dominate scholarly discussions, in Vienna such these discussions were invariably tied to social and cultural concerns as has for example been shown by Janik and Toulmin for the work of Wittgenstein (Janik and Toulmin 1973). Third, the strong identities formed in these circles influenced the identity and prospective careers of these economists in significant ways when they migrated to the New World. The bi-weekly seminar was one such ritual which was identityforming, but we will explore many more of them in section four.

The analysis of this paper of a number of intellectual communities ties in with a shift away from the study of individual scholars to creative communities. This shift occurred slowly when in physics historians of science realized that many of the great breakthroughs including quantum mechanics were achieved in small communities of about a dozen scholars (Heims 1991; Cushing 1994). A milestone was Collins's monumental study of The sociology of philosophies which showed that nearly every major philosopher had been part of a face-to-face community (Collins 1998). As Collins puts it in a later book: "the major thinkers are those most tightly connected to other important intellectuals [...]. Successful intellectuals are the most socially penetrated of introverts" (Collins 2004, 358).

This trend is also reflected by in a recent issue of the journal History of Political Economy (Spring 2011) devoted to intellectual communities.

\footnotetext{
${ }^{4}$ In the notes below I will present lists of members or rather regular participants to these circles. Membership to most of them was not a formal but an informal affair; nonetheless there was a degree of adherence to the shared perspective from some participants that others did speak of members. Such a distinction is nicely illustrated by what Alfred Schütz recounts about the involvement of his friend Felix Kaufmann with the Wiener Kreis: "Kaufmann was never a member and refused to be considered as such, yet attended their meetings regularly" (Schütz quoted in Helling 1984, 144). In the lists below you will find regular participants, rather than members.
} 
Robert Leonard contributed an article on Vienna to this issue. He describes in great detail how Oskar Morgenstern established a community of mathematical economists during the early 1930s, and how this community was broken up by the rise of fascism and the consequent migration. Leonard mentions all the important factors that will be taken up in this article: "a pervasive feeling of anxiety; the close geographical confinement; the lack of anonymity; the presence of a cultivated elite; and the existence of a lively public sphere in which politics, science, and culture were objects of serious attention" (Leonard $2011,84)$. He, however, does not develop any of these themes to explain the Viennese circles; instead they are the background to the story of Morgenstern. Consequently, Leonard does not reflect upon the nature of intellectual life in Vienna, and how practices in such circles differed from those in academia. This paper will, on the contrary, focus explicitly on the practices in such circles, and how they were situated more generally in Viennese cultural life.

In that sense this paper is in line with the efforts of Edward Timms who has sought to examine the practices and institutions which have stimulated and hampered intellectual life in interwar Vienna. For him the overlap between circles is especially important, to which, what he calls, the erotic subculture contributed further (Timms 1993; 2009). Timms, the biographer of Karl Kraus, does not pay much attention to economists, however. He instead studies more literary and artistic circles. He does observe that political factors play an increasingly important role during the Interwar period, which is true for economists as well as we will see below. So more than either Leonard or Timms we will study the alternative strategies pursued by Viennese intellectuals to establish legitimacy for their contributions and the rituals which sustained Viennese intellectual life.

In the first section, I will sketch the intellectual scene surrounding the most important of circles for our present purpose: the Mises Kreis (or Mises circle). The subsequent two sections will be devoted to the particular social space occupied by the Viennese circles; independent from the university but far from public. I will pay special attention to the alternative rituals developed outside of the official academia. Then, in the final section, I will analyze the legacy of this oral culture with its lack of formal institutions, and show how this influenced the character of Viennese economic knowledge. 


\section{WIENER KREISE, IN PLURAL}

It is important to distinguish the intellectual circles that emerged in Vienna from intellectual networks. The intellectual scene of Vienna was a rather dense network with close ties, but the circles formed communities with a shared interest and a strong sense of belonging. If networks represent the ties between individuals these circles represent the smaller groups of intellectuals who shared similar interests and frequently a shared interest and who considered themselves to be members of the circle. The most important circle for scholars interested in the economy during the first half of the 1920s was undoubtedly the Mises Kreis. It was centred around, as the name suggests, Ludwig von Mises and was held biweekly in the years 1920-1934 from October to June. The subject matter would range from philosophy and problems of phenomenology, to methodology of the social sciences, and from economics to history. The members of this circle developed the Austrian criticism of central economic planning, also known as the socialistcalculation debate. Within this circle an attempt was made to forge the 'verstehende Soziologie' of Weber with economics (Craver 1986, 14-15). It was the place where the Austrian business cycle theory, as well as the more advanced theories of capital and money were developed, and one of the few places on the Continent where marginal analysis was still discussed. It also proved to be a fertile training ground for future economists. Mises mentored Hayek, Morgenstern, Haberler, Machlup, Rosenstein-Rodan, and Karl Menger in this circle. Building on the legacy of Menger, Böhm-Bawerk, and Wieser, it was in this circle that Austrian economics became the distinct approach to economics that it is still famous for. Mises liked to describe himself as 'primus inter pares' of this seminar, but he was clearly its intellectual leader. As Mises himself describes it, the participants: "came as pupils, but over the years became my friends" (Mises 1942/1978, 97). As such it was initially a kind of continuation of the famous seminar Böhm-Bawerk had held before the war for his advanced students such as Schumpeter, Rudolf Hilferding, and Otto Bauer. The seminar evolved into an intellectual community in which Mises truly was 'primus inter pares', but this was also the stage at which several of its participants decided to start their own (complementary or rival) seminars.

In Figure 1, I have collected the circles that were most relevant to economics, as it was practiced in Vienna. In the middle, we see the 
Mises Kreis. ${ }^{5}$ The circle which was intellectually closest to the Mises Kreis is the Geistkreis. ${ }^{6}$ This circle was formed by a group of advanced students around 1921 led by Herbert Fürth and Friedrich von Hayek. The regular participants of this group overlapped to a large extent with that of the Mises Kreis, but its focus was quite different. Members were required to present on topics which were not their specialty and hence the conversations were (even) broader than in the Mises Kreis.

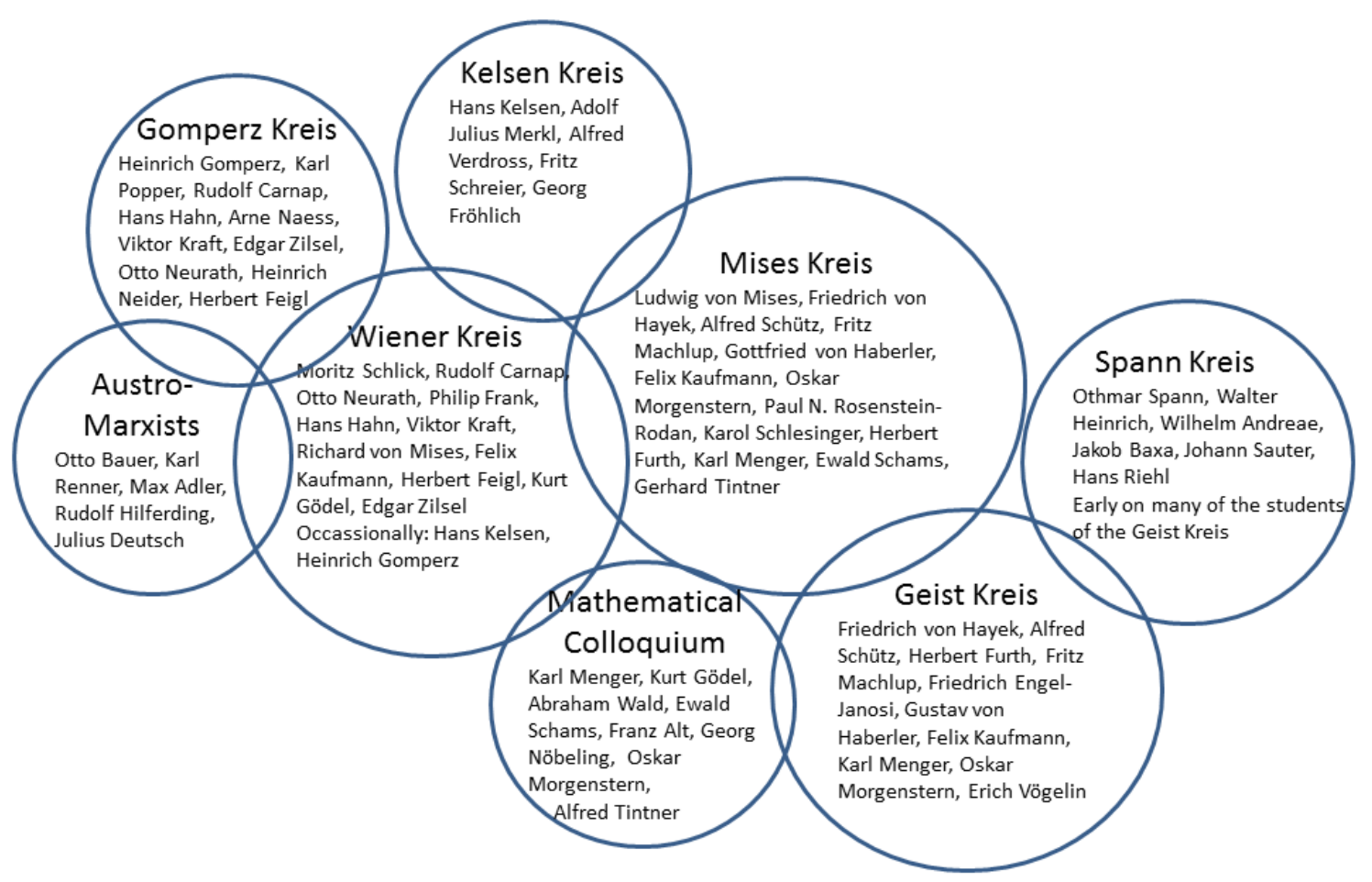

Figure 1: The Wiener Kreise most concerned with economics around 1928. For the sake of clarity I have limited the visual overlap between the circles, which in reality is often greater.

\footnotetext{
${ }^{5}$ An alphabetical full list of regular participants: Ludwig Bettelheim-Gabillon, Viktor Bloch, Karl Bode, Martha Stephanie Braun (later Steffy Browne), Walter Fröhlich (later Froehlich), Herbert Fürth, Gottfried von Haberler, Friedrich von Hayek, Marianne von Herzfeld, Felix Kaufmann, Fritz Kaufmann, Rudolf Klein, Helene Lieser-Berger, Rudolf Löbl, Getrud Lovasy, Fritz Machlup, Karl Menger, Ilse Mintz-Schüller, Ludwig von Mises, Oskar Morgenstern, Elly Offenheimer-Spiro, Paul N. Rosenstein-Rodan, Ewald Schams, Erich Schiff, Karol Schlesinger, Fritz Schreier, Alfred Schütz, Alfred Stonier, Richard von Strigl, Gerhard Tintner, Erich Vögelin (later Voegelin), Robert Wälder, Emmanuel Winternitz (list compiled from Kurrild-Klitgaard 2003, and from Craver 1986).

${ }^{6}$ An alphabetical full list of regular participants: Otto Benesch, Friedrich Engel von Janosi (later Engel-Janosi), Walter Fröhlich (later Froehlich), Herbert Fürth, Franz Gluck, Gottfried von Haberler, Friedrich von Hayek, Felix Kaufmann, Fritz Machlup, Karl Menger, Max Mintz, Oskar Morgenstern, Georg Schiff , Alfred Schütz, Erich Vögelin (later Voegelin), Robert Wälder, Johannes Wilde, Emmanuel Winternitz (list compiled from Craver 1986).
} 
Rather than just science the Geistkreis also discussed contemporary developments in literature, music and art (for a list of subjects discussed, see Engel-Janosi 1974, 225-228). In fact some of its members who graduated in law later became well-established art historians. Since the members were all roughly from the same generation there was less hierarchy than in the Mises Kreis (Craver 1986, 16-17).

During the second half of the 1920s the third important community for (future) economists was founded by Karl Menger (Carl's son): the Mathematical Colloquium. ${ }^{7}$ He and some of his friends grew dissatisfied with the anti-mathematical atmosphere in the Mises Kreis. Discussions in the mathematical colloquium were dominated by mathematical subjects, and were in fact frequented more by mathematicians than social scientists. Mises emphasized the unity of the social sciences under the banner of human action, while the members of the mathematical colloquium felt that mathematics could provide unity between the sciences. Karl Menger would end up writing a mathematical book about ethics, the Colloquium was also the place where the existence-problem of the economic general equilibrium model was first discussed and it was the place where Kurt Gödel first presented his famous impossibility theorems about logical systems. There was initially some overlap between this circle and the Geistkreis and the Mises Kreis, but this community increasingly distanced itself from the other two circles. While Hayek and Mises wrote in defence of a civilization they believed was in grave danger, Morgenstern and Menger were instead attempting to purify their economics, emptying it of any 'political' content (Leonard 1998; 2011).

To do so the participants of the Colloquium could draw inspiration from the discussions in what has become the most famous of the Wiener Kreise, the Wiener Kreis (or Vienna circle). ${ }^{8}$ The Vienna circle was not a homogenous whole, as it has been portrayed in the past. There was at least a division between the left-wing of the circle, consisting of Neurath, Carnap, Feigl, and Waismann, and a more conservative wing.

\footnotetext{
${ }^{7}$ An alphabetical (but perhaps slightly incomplete) list of regular participants: Franz Alt, Gustav Beer, Gustav Bergmann, Kurt Gödel, Hans Hahn, Bronisław Knaster, Karl Menger, Oskar Morgenstern, John von Neumann, Georg Nöbeling, Ewald Schams, Karl Schlesinger, Otto Schreier, Alfred Tarski, Olga Taussky-Todd, Alfred Tintner, Abraham Wald (compiled list based on Ingrao and Israel 1990, and on Leonard 2011).

${ }^{8}$ A more or less complete list of regular participants: Gustav Bergmann, Rudolf Carnap, Herbert Feigl, Philip Frank, Kurt Gödel, Heinrich Gomperz, Hans Hahn, Olga Hahn-Neurath, Béla Juhos, Felix Kaufmann, Hans Kelsen, Viktor Kraft, Karl Menger, Richard von Mises, Otto Neurath, Rose Rand, Josef Schächter, Moritz Schlick, Olga Taussky-Todd, Friedrich Waismann, Edgar Zilsel (Stadler 2003, 5n.).
} 
Especially in the work of Otto Neurath, but also in the pamphlet published by the circle 'Wissenschaftliche Weltauffassung', there was a clear link between socialist and emancipatory ideals and scientific knowledge (Hahn, et al. 1929/1979). The conservative wing of the circle headed by professor Schlick, however, was more interested in pure science, free of values and metaphysics. The program for which the Wiener Kreis has become famous post WWII (Reisch 2005). At the same time there were links with the Mises Kreis via the phenomenologist Felix Kaufmann. One might expect links too via the Mises brothers Ludwig and Richard, but they refused to speak to one another and pursued very different intellectual goals. Karl Menger, at various points in time, frequented all four circles we have discussed so far. He was thus well informed on a very broad spectrum of intellectual discussions, and socially very well connected.

The left-wing of the Wiener Kreis was closely connected with the Austro-Marxists, who were part of the social-democratic party which governed Vienna during the 1920s. The community of Austro-Marxists however is not really a circle, since many of the people associated with it held official positions, and many of their organizations were far more institutionalized via the Social-Democratic party. Closely associated with that side of the Wiener Kreis was Heinrich Gomperz who, for several years, also organized a circle. ${ }^{9}$ Gomperz was for a couple of years the most important teacher of Popper and his seminar was frequently attended by many of the younger members of the Wiener Kreis.

Two other circles deserve to be mentioned, as far as economics (considered broadly) is concerned. The first was formed around Hans Kelsen, ${ }^{10}$ a prominent law scholar who developed 'A pure theory of law' along positivist lines. He is more widely known because he drafted the Austrian Constitution on behest of the Austro-Marxist chancellor Karl Renner. Kelsen was a good friend of Ludwig von Mises, although not a political ally. The other circle worthy of mention is that of Othmar

\footnotetext{
${ }^{9}$ I compiled a somewhat tentative list of its frequent visitors: Rudolf Carnap, Herbert Feigl, Heinrich Gomperz, Hans Hahn, Arne Naess, Olga Hahn-Neurath, Viktor Kraft, Heinrich Neider, Otto Neurath, Karl Popper, Robert Reininger, Edgar Zilsel (from Heyt 1999, and Stadler 1994).

${ }^{10}$ I compiled a somewhat tentative list of frequent participants: Josef Dobretsberger, Georg Fröhlich, Walter Henrich, Felix Kaufmann, Hans Kelsen, Josef L. Kunz, Adolf Julius Merkl, Leonid Pitamic, Fritz Sander, Fritz-Schreier, Alfred Verdroß, Erich Voegelin. For an introduction to this circle, see Jabloner 1998, and the website of the Hans Kelsen Institute: www.univie.ac.at/staatsrecht-kelsen/kreis.php (accessed May 2014).
} 
Spann, ${ }^{11}$ who developed a universalist philosophy, and was a supporter of German nationalism (and consequently of the Anschluss). His romantic political-economic philosophies initially attracted many of the young economists such as Hayek and Morgenstern, but they soon left Spann's circle. Spann was able to exert this influence over these young students because he held one of the professorships in economics at the University of Vienna (Craver 1986).

These Kreise were not only important for the overlap between them and the mutual inspiration, but also for their mutually rivalry. The interwar work of Mises, Hayek, and Morgenstern can only be understood as part of the ongoing conversations and discussions between these circles. The famous socialist-calculation debate was waged between Otto Neurath and Ludwig von Mises, and Morgenstern carved out his position in relation and ultimately in opposition to the work of Mises. On a deeper level these communities were identity forming, one's membership to a Kreis formed one's intellectual identity. We will discover how different such identities could be from those formed along disciplinary line within academia.

\section{BETWEEN COFFEEHOUSE AND UNIVERSITY}

To understand the intellectual scenery in Vienna we need more than a description of the intellectual breadth of its circles, especially since we started this article with the purpose to explain why cultural and scholarly life was so vibrant in Vienna. The cliché about cultural life in Vienna is that it took place in the famous coffeehouses, where one could sit and chat all day while paying for only one cup of coffee. As with all clichés there's some truth to this: the entire Mises Kreis, to take one example, set off on their regular Fridays towards Café Kunstler. Contrary to the cliché, one might expect that they sometimes had more than one drink. In fact, for many Viennese these coffeehouses were much more than just a cafe, it was closer to a living room. It was where they read the newspapers, met their friends, and regularly received their mail and had their washed clothes delivered (Wechsberg 1966; Johnston 1972, 119-124; and for some additional visual material, see Brix 1998).

Like in regular living rooms, visitors were expected to observe specific rules. In certain cafés tables or even specific chairs belonged

\footnotetext{
${ }^{11}$ I have been unable to obtain more than a few of the regular participants: Walter Heinrich, Wilhelm Andreae, Jakob Baxa, Johann Sauter, Hans Riehl, and early on many of the later members of the Geistkreis.
} 
to some of the intellectual hotshots, and in some of the literary coffeehouses each group of authors had their own table. Quarrels over such tables and the rights to them would not infrequently lead to physical disputes. As homage to this tradition one can find a life-size figure of the author Peter Altenberg sitting in his regular chair in café Central. The cliché is, however, also in need of correction. Private spaces were at least as important for the circles (Fuchs 1949, v-xvi). None of the circles we discussed above actually met for their discussions in one of these coffeehouses. These discussions instead took place in private salons or offices. The availability of which depended on private wealth and professional privileges. We should not forget that the various 'Von's' we have been talking about were (inherited) titles of nobility. There was also more recently acquired wealth, the prime example was the Wittgenstein family who had acquired its wealth through iron and steel, and was estimated to be the wealthiest family of Vienna. Despite these old or new inequalities social stratification became less during the 1920s in Red Vienna.

The social consequences of this diminishing stratification were felt in the circles. Take the Wiener Kreis, where Moritz Schlick was the most prominent individual. Not only was he the only one holding a professorship but he was also much wealthier than most its members. Schlick had always refused to admit Otto Neurath in his house. Neurath had grown up in a working class environment and he cultivated this background, frequently wearing a characteristic working man's cap and refusing to adjust his accent. This led Schlick to exclaim: "I cannot invite this man; I cannot bear his loud voice" (Schlick quoted in Neider 1973, 48). Neurath was undoubtedly offended by Schlick's refusal to receive him at his house, but at the same time he made fun of the 'aristocratzic' accent of Schlick. Such inequalities, however, had further consequences. Schlick could arrange certain jobs for his students, Feigl for example became librarian at the philosophy faculty, but this also meant that Feigl was 'merely' his assistant. ${ }^{12}$

Mises too was quite good at arranging jobs for his favourite students. In 1927 he even managed to set up a new institute under the umbrella of the Chamber of Commerce where he was secretary: the 'Institut for Konjunkturforschung' (Institute for business-cycle

${ }^{12}$ Stratification also took place along 'racial' lines. Tensions remained, sometimes hidden sometimes on the surface, between Germans, Austrians, assimilated Jews and recently migrated Ostjuden. For a nuanced account of these issues in the Mathematical Colloquium, see Leonard 2010, chapter 8. 
research). The first director of this institute was Hayek who could hire Morgenstern as his assistant. On the one hand this can be interpreted as evidence that there were various opportunities for the Viennese scholars to get a job. On the other hand, it exemplifies the uncertainty in which they operated. The University of Vienna was marginalized and politicized, which made young intellectuals highly dependent on a few wealthy and powerful individuals. No wonder that the topic of migration frequently came up in the discussions of the Geistkreis. Even Mises was subject to these uncertainties and dependencies. When Böhm-Bawerk passed away and Wieser retired Mises was one of the candidates to succeed them, but the positions went to Mayer and Spann instead (Craver 1986). This decision in which Mises (and Schumpeter) were passed over reflected a general trend at the University of Vienna. It failed to hire and/or attract the most talented individuals, and hence became increasingly marginalized in Viennese intellectual life. This was further reinforced by a growing anti-Semitism in Vienna generally and at the university in particular. During the 1920s it became virtually impossible to obtain a university position as a Jew (which Mises was). Janik and Toulmin in their cultural history of Vienna even speak of an "authority gap", by which they mean the absence of any legitimating institutions in Viennese society and for intellectuals especially (Janik and Toulmin 1973, 248).

This authority gap was, however, not complete. For some of the Viennese intellectuals there was the opportunity of association with the social-democrats and their government. The social-democrats set up extensive social programs, most famously to solve the housing conditions and shortage in Vienna. This development did not improve matters, however, for the more neutral or liberal intellectuals. For them the changing political wind meant that political positions which many Viennese economists had occupied before WWI became unavailable. Schumpeter, as an exception, did obtain such position. And while he certainly tried to combine his position of the neutral expert with the goal of the socialization of the economy, his position was soon untenable (McCraw 2007, 96-103).

Another institution which was still standing strong was the gymnasium system, which provided a solid basis for many in the Viennese elite. Gymnasiums such as the Schottengymnasium, which Böhm-Bawerk, Wieser, and no less than three later Nobel Prize winners 
attended, were of a high quality. ${ }^{13}$ On the other hand the gymnasium system also reflected and reinforced a big divide between the elite and the middle classes. In his memoirs, Karl Menger points to yet another factor which helped Viennese intellectual life flourish:

The unusually large proportion of professional and business people interested in intellectual achievement. Many members of the legal, financial, and business world; publishers and journalists, physicians and engineers took intense interest in the work of scholars of various kinds. They created an intellectual atmosphere which, I have always felt, few cities enjoyed (Menger 1994, 9).

This interested group of professionals regularly participated in the Kreise. To give some examples from the participants of the Mises Kreis: Mises combined it with his work at the Chamber of Commerce, Karl Schlesinger was also a banker, Machlup worked in his parents' cardboard factory, and Schiff was a newspaper editor (Schulak and Unterköfler 2011, 133-135). It was from this professional class, also, that a more general audience could be drawn, for example for the public lecture series which various members of the Wiener Kreis organized.

Intellectual life as a consequence became separated from the official institutions. Famous is the artistic Viennese 'Sezession' (literally: separation) movement, which sought independence from the existing artistic styles and institutions. It is helpful to think of Viennese intellectual life as also separating itself from the official institutions. This is in line with Schorske's analysis of the failure of political liberalism in Vienna. This meant that intellectual life flourished, despite the lack of official institutions. For the scholar, however, it meant that, like the artists of the Sezession, he or she was in need of alternative institutions, alternative sources of finance, alternative sources of legitimacy, even an alternative identity.

\section{THE RITUALS OF THE KREISE}

Academic life is so full of rituals, that we sometimes hardly notice them: extensive rituals when $(\mathrm{PhD})$ students graduate, or when a professor accepts a chair (or retires from one), and smaller rituals such as the celebration of centenaries of famous predecessors, or the opening of

\footnotetext{
${ }^{13}$ Julius Wagner-Jauregg won the Nobel Prize in Medicine in 1927, and Konrad Lorenz and Karl von Frisch shared the Nobel prize in Medicine with Nikolaas Tinbergen in 1973.
} 
our academic year. Such rituals have a double function: they honour the people involved, the renowned scholar or the graduate, but they also legitimize the institutions that organize such rituals. Such legitimization was not self-evident in Viennese intellectual life. A position at the University of Vienna was the exception rather than the rule, and the continued conversation often depended on particular individuals within the Kreise, rather than on more formalized or official institutions. It should thus perhaps come as no surprise that Viennese intellectual life was filled with alternative rituals and strategies to establish legitimacy. Such rituals helped establish a scholarly identity for the intellectuals in Vienna, so that they could give an answer to some of those piercing everyday questions: who are you and what do you do?

Although no one has to my best knowledge ever paid particular attention to such rituals in the Wiener Kreise, we are fortunate to know quite a bit about them. The meetings of the Mises circle always started punctually at seven on a Friday evening. Mises would be sitting at his desk and usually he had a large box of chocolates-quite a luxury in years of hyperinflation-which he passed around. The meeting would last until half past nine or ten, after which the participants would have dinner at the Italian restaurant 'Anchora Verde', and those who had not yet had enough would continue to café 'Künstler' (Kurrild-Klitgaard 2003, 47). Undoubtedly the most striking ritual of the Mises Kreis is the songs which Felix Kaufmann wrote in honour of the seminars. The songs deal with the critical spirit of the circle ('Geschliffener Geist in Mises Kreis'), particular debates within the circle, and the Austrian tradition ('Der letzte Grenadier der Grenznutzenschule'). Other songs were written for special occasions: a song of celebration for the opening of the statistical institute and goodbye song to Mises when left Vienna to take up a post in Geneva.

Now it is easy to think of these songs as a kind of curiosity, but that would be too easy. Many years later Haberler was still able to sing these songs word for word, and he emphasizes that all regular participants could recite them (Haberler in Kaufmann 1992, 9-10). The songs were written to popular melodies and Haberler stresses that these songs were meant to be sung, not to be read (although even reading them is quite a delight). Such rituals established a certain rhythm to the meetings of the Mises Kreis, and provided a sense of belonging where the university could not do so. The songs also served to legitimize the Mises Kreis, take for example the following fragment: 
An economist moved to Germany

A learned position to pursue

This should have been a certainty

For in Vienna he'd learned a thing or two

But the good man learned the tragic tale

Marginal Utility was deceased (Kaufmann 1992, 21-22). ${ }^{14}$

In the eponymous song of the Mises circle, the rituals discussed included the delicious chocolates that were consumed. In the final stanza Kaufmann wonders whether all these intellectual discussions lead anywhere, while life outside goes on as usual. Was it not easier to follow the stream, instead of attempting to change its course? Only to conclude affirmatively: "And yet there's no tradeoff at hand / Somehow we must take a stand" (Kaufmann 1992, 28). ${ }^{15}$

Such rituals established internal coherence and legitimacy, but the overlap between the circles meant that a strong internal identity would also become known in other circles. In fact there was a curious interdependence between all these Kreise. The identity of such circles was often defined in opposition to other circles. The Mises Kreis stood in opposition to the positivism of the Wiener Kreis and the universalism of the Spann Kreis. Meanwhile the Geistkreis was more informal and more cultural than the Mises Kreis. It was also only open to men and restricted to twelve members. In fact a degree of secrecy was not alien to these circles, Mises in his recollections written around 1940 explains: "Outsiders knew nothing of our meetings; they merely saw the works published by the participants" (Mises 1942/1978, 98). But one might critically ask who in the Viennese elite was really an outsider? The Mises Kreis was well known in intellectual circles in Vienna and abroad, from which visitors occasionally joined the seminar. The most prominent foreign visitor was perhaps Lionel Robbins, who would later offer Hayek a professorship at the LSE. Nonetheless access to particular circles could be a sensitive issue. This becomes particularly clear from the following passage from Popper's autobiography:

\footnotetext{
${ }^{14}$ From "Dei Grenznutzenschule", translated as "The Grenadier of the Marginal Utility School" by Arlene Oost-Zinner at http://mises.org/misestributes/misessongs.asp (accessed September 2014).

${ }^{15}$ From "Das Mises-Kreis-Lied", translated as "The Song of the Mises Circle" by Arlene Oost-Zinner at http://mises.org/misestributes/misessongs.asp (accessed September 2014).
} 
The Circle [Wiener Kreis] was so I understood, Schlick's private seminar, meeting on Thursday evenings. Members were simply those whom Schlick invited to join. I was never invited, and I never fished for an invitation. But there were many other groups, meeting in Victor Kraft's or Edgar Zilsel's apartments, and in other places; and there was also Karl Menger's famous 'Mathematische Colloquium'. Several of these groups, of whose existence I had not even heard, invited me to present my criticisms of the central doctrines of the Vienna Circle (Popper 1976, 84).

The quote not only highlights the opposition between the various circles, especially against the most prominent, but also the partly open and partly closed nature of the circles. Popper's labelling of Schlick's seminar as 'private' is especially telling, and revealing of the powerful position of Moritz Schlick. Popper's autobiography has become an archetypical example of how unreliable autobiographies can be, but it is beyond doubt that the tension between him and the Wiener Kreis was as much social as intellectual. Popper's biographer Cohen writes about the issue: "his personality made collaboration difficult. Even Popper's defenders, Carnap and Kraft [both members of the Wiener Kreis], admitted that he was a social problem" (Hacohen 2000, 209). ${ }^{16}$

The Wiener Kreis, too, is interesting to study for its search for legitimacy. Its most famous publication is a manifesto 'Wissenschaftliche Weltauffassung', which is usually translated somewhat awkwardly into 'scientific world-conception'. But let us pause for a moment, to realize what is happening here: a group of philosophers (!) who seek to purify science from metaphysics and values publish a manifesto. The manifesto is, and was, a rather revolutionary form: Marx and Engels published a manifesto pamphlet, and the Italian Futurists published one to declare a revolution in art. It is not, however, the form one would expect from a group of philosophers, let alone from one that is looking for the foundations of objective knowledge. In fact the most traditional of them, Moritz Schlick, was seriously taken aback

\footnotetext{
${ }^{16}$ The insider-outsider discussion is also interesting with respect to the very negative essays that both Schumpeter and Hayek have written about intellectuals; see Schumpeter 1943/1976, 145-155; and Hayek 1949. One is tempted to also think of the Viennese scholars of the interwar period as (public) intellectuals but in their search for legitimacy they had to distance themselves from outsiders. Their repeated arguments against intellectuals or men of science are perhaps best understood as an attempt to create a professional identity outside academia, read as such they are testimonies of a certain existential 'angst'.
} 
by the publication (Mulder 1968). ${ }^{17}$ The pamphlet as a scientific form is of course still far from accepted, but understood as an alternative strategy to seek legitimacy it makes sense. It also succeeded, in the sense that it gave the Wiener Kreis a very clear identity to the outside world, and the movement soon attracted followers, disciples and opponents in other countries (Gruen 1939; McGill 1936). It, furthermore, provided the stimulus for cooperation between members of the Wiener Kreis and the cultural avant-garde in Europe (Galison 1990). Membership of a circle as such became a mark of expertise, but also a lasting allegiance to a particular intellectual position and a certain style of doing science.

Looking back on the interwar situation in Vienna it becomes clear, however, that the situation was ultimately unstable. The uncertainty and the lack of official positions made it tempting to migrate. The more senior and successful scholars were the first to migrate, not uncommonly before the political situation in Vienna became an acute threat. Hayek already migrated in 1931. The domestic situation became particularly problematic in 1934 when Dollfuss rose to power. Between 1934 and 1938, the year of the Anschluss, Austria was ruled by the Austrofascists and public life became more restricted. Mises, who expected the worst for the future, left for Geneva in 1933, only to move to New York in 1940. The Wiener Kreis was particularly disturbed by the shooting of Moritz Schlick in 1936 by a former student. Although the murder was not motivated by anti-Semitic sentiments, the press described it as such. Migration was not easy for everyone; those with little international visibility depended on friends from Vienna who migrated earlier. Popper, for example, had to migrate to New Zealand in 1937 where he held a low-prestige job at a university. The adaptation to these foreign and academic cultures would require a separate article, but it is safe to say that this process occurred far from smoothly. Individuals with considerable prestige in the Kreise of Vienna frequently ended up at the bottom of the ladder, employed at marginal universities.

It is tempting to argue that first Austro-fascism and later the Anschluss with Nazi-Germany caused the migration, but that might also be too simple. The social situation for many of the intellectual

\footnotetext{
${ }^{17}$ Schlick was nonetheless very aware of the revolutionary nature of the philosophical project in which he and his fellow Wiener Kreis members were involved as is evident from his 'Die Wende der Philosophie' (1930).
} 
talents was uncertain even apart from the political situation. On the one hand the Viennese intellectuals were, as Fürth wrote years later to Hayek, "spoiled" by the intellectual stimulation around them (Fürth quoted in Hennecke 2000, 25). On the other hand they could not obtain an official academic position, they were dependent on not more than a handful of powerful and wealthy individuals, and there were few signs of future improvement. So when Hayek was offered a position at the LSE he knew what he left behind, but also what he stood to gain. What helped in his particular case was that he was offered a full professorship. Overall it is doubtful how long Vienna would have been able to retain its greatest talents, even if the political situation would have remained stable.

\section{THE LEGACY OF AN ORAL INTELLECTUAL CULTURE}

The vibrancy of Viennese intellectual life tends to cause quite a bit of nostalgia. That nostalgia is wonderfully cultivated in some of the memoirs about the period (Zweig 1943; Spiel 1987). More than anything, however, we should ask why this intellectual culture disappeared. Reisch (2005) examines the disappearance in detail for the Wiener Kreis.

He argues that it never came to fruition because it was smothered before it could really flourish. He suggests that the central ideal from within the Viennese intellectual scene has been lost and forgotten: the ideal of the unity of science. Reisch shows that this was not as much a philosophical ideal as it was a practical program: "the unity of science program transformed from a practical, collaborative goal to a more narrow academic thesis, [...] it became an empirical hypothesis about science [...] after it was decoupled from the ideal of active collaboration" (Reisch 2005, 375-376). This is not the place to debate the merits of the unity of science thesis or these other social projects. But what is interesting for us is the shift Reisch describes away from these social goals, towards purely philosophical and academic goals. Reisch is not the only one with this sentiment. Janik and Toulmin (1973) in their study of Wittgenstein's Vienna also lament the professionalization which made the position of therapeutic philosophers in modern intellectual life increasingly difficult. Both Reisch and Janik and Toulmin recognize that within the Viennese tradition there is no clear separation between science and politics or philosophy and life. They argue that social, cultural and sometimes political goals went hand in hand with scholarly concerns for the Viennese. 
This unique feature of the Viennese tradition combined with its breadth often puzzled outsiders and it made moving to another intellectual climate, another country, or rather into a university a difficult process. ${ }^{18}$ When Schumpeter visited the U.S.A. in 1913 he was asked to deliver a lecture by Seligman, an economics professor at Columbia. Seligman's description of the lecture is a wonderful example of this confusion:

[He did not only speak of economics] but the relation of economics to psychology and sociology. He was-what is very unusual-both brilliant and profound; his choice of novel illustrations taken from a great variety of different fields, shows a surprising breadth of culture, which is unusual in a specialist (Seligman, quoted in McCraw 2007, 81).

But Schumpeter was no specialist, and never became one; he was a student of civilization, schooled in wide cultured conversation not with just Wieser or Böhm-Bawerk, but with Marxists, Max Weber, and artists from Vienna. This is also exemplified by Hayek's tribute to his mentor Wieser. Hayek chose not to compare him to a great economist of the past, but to Goethe, the great symbol of German culture, who had: "[w]ide-ranging interests encompassing all fields of culture and art, worldly wisdom and the worldly tact of the minister of Old Austria combined with an aloofness from daily trivia" (Hayek 1926/1992, 125). It was a description that suits intellectual life in interwar Vienna just as well.

The reception of Hayek in the U.S.A. is another prime example of such confusion. ${ }^{19}$ He is often associated with the Chicago school of economics, because he held a position in Chicago. But Hayek was never offered a position at the economics department in Chicago. There is still no absolute clarity regarding the reasons for this, but it is clear that there were concerns about the non-economic nature of his work. Friedman, the main figure within the Chicago school, explained why Hayek was not offered a job in an interview from 2000: "[m]y understanding is that this was because, at that stage, he [Hayek] really

\footnotetext{
${ }^{18}$ Reisch study of the migration of the Wiener Kreis contains many examples of such difficulties; see Reisch 2005.

${ }^{19}$ For reasons of space it is not possible to discuss all major economic figures, but it is worth noting that one of Mises's students, Alfred Schütz, suggests that Mises was not hired because it was believed that he was too practically oriented and not academic enough; see Kurrild-Klitgaard 2003, 52.
} 
wasn't doing any economics" (Friedman quoted in Cassidy 2000). In fact, it should not really surprise us that Hayek was not considered to be a professional economist in 1950. His book on capital theory from the 1930s was not very well received, and thus his main claim to fame was The road to serfdom, a political rather than an economic book.

Hayek was instead hired at the 'Committee of Social Thought' which was oriented much more broadly. In fact Hayek was happy with this position precisely because it was concerned with what he described as 'borderline problems in the social sciences', and in an interview he even claimed that he was bored with the purely economic atmosphere at the LSE. In that same interview he speaks very positively about especially the initial period on this committee:

I announced a seminar on comparative scientific method, and the people who came included Sewall Wright, the great geneticist; Enrico Fermi, the physicist; and a crowd of people of that quality. It only happened once; we couldn't repeat this. But that first seminar I had in Chicago was one of the most interesting experiences I had (Hayek, interviewed by Buchanan 1979, 262).

Hayek was once again back in cultured conversation with scholars from many fields. And not just scholars, the committee on social thought also invited individuals from the literary world. Hayek was never happy in just one discipline, but thrived in an atmosphere like the one in which he came of age.

In fact, at one point there was the opportunity to restart in Vienna what had been lost during WWII. In the same interview with James Buchanan, Hayek explains that he could get money from the Ford Foundation, a lot of money, to start a new centre in Vienna. Then Buchanan asks whether this was to reestablish the University of Vienna, to which Hayek responds quite accurately: "[w]ell, to reestablish its tradition" (Hayek 1979, 253). Of course reestablishing the University of Vienna would have been nearly a contradiction in terms, for in many fields it had never really been established, and it certainly had never been the centre of scholarly life. What Hayek sought to do was to reestablish its tradition, and for this he needed to bring the people back: "to bring all the refugees who were still active back to Vienna-people like Schrödinger and Popper and-Oh, I had a marvelous list! I think we could have made an excellent center" (Hayek 1979, 253). This is Hayek's nostalgia for a tradition, for the Viennese conversation, which always 
took place on the borderlines between disciplines and between science and society. Needless to say this initiative remained a nostalgic dream and never materialized.

\section{CONCLUSION}

In this paper we have studied the practice of intellectual life in Vienna. Central in this practice were the circles in which intellectual conversations took place. The conversations were the practice par excellence of Viennese intellectual life; not experiments, not armchair observations, not statistical methods, not modelling, but talking. One of the downsides for the historian is that little remains of such conversations. In this chapter I have analyzed the setting in which these conversations took place, and by which rituals they were surrounded, but the conversations themselves are permanently lost. All we have left are some lists of topics discussed during the seminars. In fact if one looks back on the interwar period one notices a peculiar absence of written work. Hayek hardly published anything during the 1920s, and was hired at the LSE based on the lectures he delivered there. Mises wrote his most important books before and after the flourishing period of his seminar. And while I certainly do not want to claim that there was no output, it seems that the conversations were indeed more important than the written word. The written output was produced later when they migrated to an academic culture in which the written word was far more important than it had been in Vienna. If they did write it was just as often a contribution to some contemporary political debate as it was an academic paper. In fact a recent volume which collects the writings of Mises during the interwar period shows that his reflections on political and economic developments far outweigh the more traditional academic issues (Mises 2002).

In this paper I have demonstrated the unique structure of Viennese cultural world with special attention to economics. This institutional setting not only influenced the practices of economic thinkers, but also the content of their contributions. Except for the participants of the Mathematical Colloquium, the Viennese economists were involved with, and felt attached to the cultural and political context of Vienna and Europe. These circles shaped their intellectual identities, and when they migrated they kept looking for institutional settings which allowed them to transcend disciplinary boundaries, and contribute on theoretical, social, and political levels. 


\section{REFERENCES}

Beller, Steven. 1989. Vienna and the Jews 1867-1938: a cultural history. Cambridge: Cambridge University Press.

Brix, Emil. 1998. Ein Fenster nach Europa: die neue freie Presse als Zeitung des liberalen Bürgertums. In Ein Stück Oesterreich, eds. J. Kainz, and A. Unterberger. Wien: Holzhausen, 54-60.

Cassidy, John. 2000. The Hayek century. Hoover's Digest: Research and Opinion on Public Policy, (3). http://www.hoover.org/research/hayek-century (accessed September 2014).

Coen, Deborah R. 2007. Vienna in the age of uncertainty: science, liberalism, and private life. Chicago: University of Chicago Press.

Collins, Randall. 1998. The sociology of philosophies: a global theory of intellectual change. Harvard: Harvard University Press.

Collins, Randall. 2004. Interaction ritual chains. Princeton: Princeton University Press.

Craver, Earlene. 1986. The emigration of the Austrian economists. History of Political Economy, 18 (1): 1-32.

Cushing, James T. 1994. Quantum mechanics: historical contingency and the Copenhagen hegemony. Chicago: University of Chicago Press.

Engel-Janosi, Friedrich. 1974. Aber ein stolzer Bettler: Erinnerungen aus einer verlorenen Generation. Graz: Styria.

Fuchs, Albert. 1949. Geistige Strömungen in Österreich 1867-1918. Wien: Globus Verlag.

Galison, Peter. 1990. Aufbau/Bauhaus: logical positivism and architectural modernism. Critical Inquiry, 16 (4): 709-752.

Gruen, William. 1939. What is logical empiricism. Partisan Review, 6 (5): 64-77.

Hacohen, Malachi H. 2000. Karl Popper, the formative years, 1902-1945: politics and philosophy in interwar Vienna. Cambridge: Cambridge University Press.

Hahn, Hans, Otto Neurath, and Rudolf Carnap. 1979 [1929]. Wissenschaftliche Weltauffassung: der Wiener Kreis. In Otto Neurath: wissenschaftliche Weltauffassung, Sozialismus und Logischer Empirismus, ed. Rainer Hegelsmann. Frankfurt am Main: Suhrkamp Verlag, 79-101.

Hayek, Friedrich A. 1992 [1926]. Friedrich von Wieser (1851-1926). The collected works of F. A. Hayek: volume IV, the fortunes of liberalism. London: Routledge, 108-125.

Hayek, Friedrich A. 1949. The intellectuals and socialism. The University of Chicago Law Review, 16 (3): 417-433.

Hayek, Friedrich A. 1979. Interviews with Hayek [1983]. Introduced by Armen A. Alchian. https://mises.org/books/hayek_oral_history.pdf (accessed October 2014).

Heims, Steve J. 1991. Fritz London and the community of quantum physicists. In World views and scientific discipline formation, ed. William R. Woordward. Dordrecht: Kluwer, 171-190.

Helling, Ingeborg Katharina. 1984. A. Schutz and F. Kaufmann: sociology between science and interpretation. Human Studies, 7: 141-161.

Hennecke, Hans Jörg. 2000. Friedrich August von Hayek: die Tradition der Freiheit. Düsseldorf: Verlag Wirtschaft und Finanzen. 
Heyt, Friso D. 1999. Popper's Vienna: a contribution to the history of the ideas of critical rationalism. Innovation: The European Journal of Social Science Research, 12 (4): 525-541.

Ingrao, Bruno, and Giorgio Israel. 1990. The invisible hand. Cambridge: MIT Press.

Jabloner, Clemens. 1998. Kelsen and his circle: the Viennese years. European Journal of International Law, 9 (2): 368-385.

Janik, Allan, and Stephen Toulmin. 1973. Wittgenstein's Vienna. New York: Simon \& Schuster.

Johnston, William M. 1972. The Austrian mind: an intellectual and social history, 18481938. Berkeley: University of California Press.

Kaufmann, Felix. 1992. Wiener Lieder zu Philosophie und Ökonomie. Stuttgart: Gustav Fischer Verlag.

Kurrild-Klitgaard, Peter. 2003. The Viennese connection: Alfred Schutz and the Austrian school. The Quarterly Journal of Austrian Economics, 6 (2): 35-67.

Leonard, Robert J. 1998. Ethics and the excluded middle: Karl Menger and social science in interwar Vienna. Isis, 89 (1): 1-26.

Leonard, Robert J. 2010. Von Neumann, Morgenstern, and the creation of game theory: from chess to social science, 1900-1960. Cambridge: Cambridge University Press.

Leonard, Robert J. 2011. The collapse of interwar Vienna: Oskar Morgenstern's community, 1925-1950. History of Political Economy, 43 (1): 83-130.

Leser, Norbert. 1981. Das geistige Leben Wiens in der Zwischenkriegszeit. Wien: Oesterreichischer Bundesverlag.

McCraw, Thomas K. 2007. Prophet of innovation: Joseph Schumpeter and creative destruction. Cambridge: Belknap Press of Harvard University Press.

McGill, V. Jerauld. 1936. An evaluation of logical positivism. Science \& Society, 1 (1): 45-80.

Menger, Karl. 1994. Reminiscences of the Vienna circle and the mathematical colloquium, eds. Louise Golland, Brian McGuiness, and Abe Sklar. Dordrecht: Kluwer Academic.

Mises, Ludwig von. 1978 [1942]. Ludwig von Mises, notes and recollections. South Holland: Libertarian Press.

Mises, Ludwig von. 1978 [2002]. Selected writings of Ludwig von Mises: between two world wars, ed. Richard M. Ebeling. Indianapolis: Liberty Fund.

Mulder, Henk L. 1968. Wissenschaftliche Weltauffassung: der Wiener Kreis. Journal of the History of Philosophy, 6 (4): 386-390.

Neider, Heinrich. 1973. Memories of Otto Neurath. In Empiricism and sociology, eds. Marie Neurath, and Robert S. Cohen. Dordrecht: D. Reidel Publishing Company, 45-49.

Popper, Karl R. 1976. Unended quest: an intellectual autobiography. Glasgow: William Collins Sons \& Co.

Reisch, George A. 2005. How the Cold War transformed philosophy of science: to the icy slopes of logic. Cambridge: Cambridge University Press.

Schlick, Moritz. 1930. Die Wende der Philosophie. Erkenntnis, 1 (1): 4-11.

Schorske, Carl E. 1980. Fin-de-siècle Vienna: politics and culture. New York: Alfred Knopf. 
Schulak, Eugen M., and Herbert Unterköfler. 2011. Austrian school of economics: a history of its ideas, ambassadors, and institutions. Auburn: Ludwig von Mises Institute.

Schumpeter, Joseph A. 1976 [1943]. Capitalism, socialism, and democracy. London: George Allen \& Unwin.

Spiel, Hilde. 1987. Vienna's golden autumn. London: Weidenfeld and Nicolson.

Stadler, Friedrich. 1994. Heinrich Gomperz und Karl Popper im Kontext des logischen Empirismus. In Heinrich Gomperz, Karl Popper Und Die Oesterreichische Philosophie, ed. Friedrich Stadler. Amsterdam: Rodopi, 2-29.

Stadler, Friedrich. 2003. What Is the Vienna circle?: some methodological and historiographical answers. In The Vienna circle and logical empiricism: reevaluation and future perspectives. Dordrecht: Kluwer Academic, XI-XXIII.

Timms, Edward. 1993. Die Wiener Kreise: schöpferische Interaktionen in der Wiener Moderne. In Die Wiener Jahrhundertwende: Einflüsse, Umwelt, Wirkungen, eds. Jürgen Nautz, and Richard Vahrenkamp. Wien: Böhlau Verlag, 128-143.

Timms, Edward. 2009. Cultural parameters between the wars: a reassessment of the Vienna circles. In Interwar Vienna, eds. Deborah Holmes, and Lisa Silverman. Rochester: Camden House, 21-30.

Wechsberg, Joseph. 1966. The Viennese coffee house: a romantic institution. Gourmet, 12: 12-16.

Wistrich, Robert S. 1996. Intellectuals and mass politics in fin-de-siècle Vienna. In The intellectual revolt against liberal democracy 1870-1945, eds. Zeev Sternhell, and Jacob L. Talmon. Jerusalem: The Israel Academy of Sciences and Humanities, 70-86.

Zweig, Stefan. 1943. The world of yesterday. New York: The Viking Press.

Erwin Dekker is assistant professor in cultural economics at the Erasmus University in Rotterdam, the Netherlands. He has recently completed his $\mathrm{PhD}$ thesis The Viennese students of civilization: humility, culture and economics in interwar Vienna and beyond. He has published in the fields of cultural economics, economic methodology, and intellectual history, and he is currently working on valuation regimes. Previously he has worked as lecturer at the European Studies department at the University of Amsterdam, where he specialized in political economy.

Contact e-mail: <e.dekker@eshcc.eur.nl> 